\title{
Study Genetic Variation Using DNA Molecular Markers and Identification Physiological Races of Wheat Stripe (yellow) Rust Puccinia striiformis f.sp tritici during 2010-2014 in Some Regions of Syria
}

\author{
Shoula Kharouf ${ }^{1}$, Fawaz Azmeh ${ }^{1},{ }^{2}$ and Buthainah N. Alsalamah ${ }^{1}$ \\ 1. National Commission for Biotechnology (NCBT), P.O. Box: 31902 Damascus, Syria \\ 2. Damascus University Faculty of Agriculture, (G.C.B.T), 0096311 5138309, Damascus, Syria
}

\begin{abstract}
Yellow Rust (stripe) rust (Puccinia striiformis West. f. sp. tritici) is one of the most epidemic diseases infect wheat in cold and wet regions. In 1988, this disease caused a loss of seasonal production amounted $70 \%$ on wheat variety Mexipak in Syria, and recurrent infection in 2010, caused by a virulent race called Yr27, caused a considerable loss in the production of bread wheat cultivars (Cham 8, Cham 6 particularly) amounted 90\%. Recently, 15 races of yellow rust had been addressed in Syria for seasons 2010-2014; 159E256, 166E254, 166E256, 255 E112, 0 E0, 64 E 6, 230 E150, 0 E 18, 198 E130, 166 E150, 102 E160, 128 E0, 126 $\mathrm{E} 150,214 \mathrm{E} 150$, and $6 \mathrm{E} 16$. The race $6 \mathrm{E} 16$ was the most frequent during the two seasons, while the race $255 \mathrm{E} 112$ was the most virulent, followed by the race 230E222 and the race 0E0 was the weakest one. This study revealed the presence of fourteen newly observed races in Syria. Molecular Variance Analysis of Molecular Variance (AMOVA) of 55 yellow rust Puccinia striiformis f.sp tritici isolates examined by Amplify Fragment Length Polymorphism (AFLP) revealed high genetic variation within population, and the dimensional scale analysis (MSD) and tree diagram showed that the Syrian yellow rust isolates were clustered in three groups: the first group contained isolates derived from durum wheat, the second one contained bread wheat isolates, but the third was made of isolates derived from both durum and bread wheat species.
\end{abstract}

Key words: Wheat yellow (stripe) rust, Puccinia striiformis West f. sp. tritici, DNA molecular markers, AFLP, PCR, races Syria.

\section{Introduction}

Yellow rust, also known as stripe rust, caused by Puccinia striiformis $f$. sp. tritici, is a major disease that affects wheat production worldwide [1-6], since the yield loss can be as high as $70 \%$ [7]. In Syria, particularly the irrigated fields and the northern areas, where the rainfall rate is high, the severity of infection was up to $80 \%$, and the yield loss of the susceptible cultivar Mexipak was $29 \%$ [8, 9], but the very damaging epidemic, included Iraq and Turkey, took place in 2010, and heavily infected some improved cultivars; Cham 8 and Cham 6 particularly [10]. As that, Yellow rust was considered as a main wheat

Corresponding author: Shoula Kharouf, Ph.D., research field: fungal diseases and molecular biology. infection in the country [11].

Moreover, wheat cultivars having excellent stripe rust resistance often become susceptible after being grown for some periods of time because of the frequent development of new virulence by stripe rust races [12-14], and the spores of these emerging races spread by the wind $[15,16]$ and help overcoming cultivars carrying the resistance genes in other different countries [17]. In addition to virulence studies, molecular markers are being applied widely to characterize the genetic diversity and phylogenetic relationships in the pathogen populations, and to study the disease epidemiology [18].

The Amplified Fragment Length Polymorphism (AFLP) is one of the most important of these 
molecular marker-based techniques, because it also provides a greater understanding of the dynamics of yellow rust fungus community [19, 20].

This study aimed to assess the genetic variance of 55 yellow rust Puccinia striiformis f.sp tritici isolates collected from many regions in Syria during seasons 2010-2014, using Amplified Fragment Length Polymorphism (AFLP) as a molecular marker to detect the genetic variation related to the geography, within the pathogen population.

\section{Materials and Methods}

\subsection{Yellow Rust Isolates}

The infected leaves had been collected from the infected wheat fields in Syria; 171 and 164 fields during the seasons 2010 and 2011-2014, respectively, according to the hierarchical sampling method. The survey included both farmers' fields and that belonging to the agricultural scientific research centers, representing all the Syrian environmental areas. 33 out of 171 samples, of the first season, each of them represented a single spore isolate, but the number of isolates was 22 out of 164 ones for the second season 2011-2014.

\subsection{Isolation and Propagation of the Pathogen}

This study was carried out in the laboratory of wheat diseases in the International Center for Agricultural Research in the Dry Areas (ICARDA) during season 2010-2014. Because study of genetic variation is so difficult using the DNA from mycelium, due to the penetration process into the tissues of the host [21], the molecular studies depend on the Urediniospore DNA [22]. The Urediniospore of $P$. striiformis were collected by a single pustule, and multiplied on seedlings of the susceptible bread wheat cultivar; Morocco that grown in small plastic pots filled with a sterile mixture of clay soil, sand and pitmose with ratio of 1: 1.3: 2.7, respectively, and after germination, a solution of Maleic Hydrazide $(0.25 \mathrm{~g} / \mathrm{L})$ was added to the irrigation water. The infected seedlings were incubated at controlled conditions of temperature $\left(10 \pm 2{ }^{\circ} \mathrm{C}\right)$, relative humidity (70\%-80\%) and alternating lighting (16:8 hours of light: dark) for 24 hours, then the temperature was risen to $(15 \pm 2)$. The Urediniospore were collected after 17 days of infection and re-multiplied again following the same steps above, till to obtain a quantity of these spores sufficient for downstream applications. Yellow rust assessment was made 17 days after infection using a 0-9 disease-scoring scale [23]. Infection types 0-6 and 7-9 were classified as avirulent and virulent, respectively [24, 13], and the nomenclature of $P$. striiformis was given to each isolate using the standard differential sets according to Johnson et al. [25].

\subsection{DNA Extraction}

DNA was extracted according to the protocol in the laboratory of biotechnology at (ICARDA), 20-50 mg of Lyophilized Urediniospore isolate was crushed using $50 \mathrm{mg}$ fine sand and metal ball. After that, $1 \mathrm{~mL}$ of the extraction solution (1M Tris-HCL, $5 \mathrm{M} \mathrm{NaCl}$, 0.5M EDTA, CTAB) was added to the $100 \mathrm{mg}$ of each powdered isolate, and incubated in a water bath at $60-65{ }^{\circ} \mathrm{C}$ for 60 minutes. Then $1 \mathrm{~mL}$ of the mixture Chloroform/Iso-amyl-alcohol (1:24, v:v) was added, and stirred gently until forming an emulsion, then centrifuged at 10,000 rpm for 10 minutes. The upper layer containing the DNA was transferred to another $1.5 \mathrm{~mL}$ tube. DNA was precipitated by adding $1 \mathrm{~mL}$ of the cold isopropanol $\left(-20^{\circ} \mathrm{C}\right)$, then centrifuged to discard the supernatant. DNA was washed with $75 \%$ cold ethanol $\left(-20^{\circ} \mathrm{C}\right)$ for several times till the pellet became diaphanous to be dried by keeping the tube open at the room temperature. Finally, DNA was dissolved in $100 \mu \mathrm{L}$ of TE buffer (1 M Tris base, 0.5 M EDTA). The concentration and purity of DNA were estimated using a spectrophotometer at $260 \mathrm{~nm}$.

\subsection{AFLP Test}

Seven combinations of primers: P16 + M 17, P16 + 
M88, P16 + M183, P16 + M269, P20 + M 88, P24 + M 17and P24 + M301 were applied to 10 fungus races. Only primers that gave Polymorphic bands were chosen; P16 + M 17, P16 + M88 (Table 1), and the rest were excluded.

\subsection{DNA Digestion}

For each isolate, $1.3 \mu \mathrm{l}$ of genomic DNA (80 ng/ $\mu \mathrm{L})$ was digested with a mixture of tow restriction enzymes; Ecorl and Msel $(0.8 \mu \mathrm{L})$ for $4 \mathrm{~h}$ at $37{ }^{\circ} \mathrm{C}$ in $1 \mathrm{X}$ reaction buffer $(2 \mu \mathrm{L}$ of $10 \mathrm{X})$ at $10 \mu \mathrm{L}$ final volume. The enzymes were deactivated by incubating at $70{ }^{\circ} \mathrm{C}$ for 15 min then placing directly in the ice for several minutes.

\subsection{Ligation of Adapters}

The restricted DNA $(10 \mu \mathrm{L})$ was ligated with double-stranded adapters by adding $9.6 \mu \mathrm{L}$ of adapter ligation solution, and $0.4 \mu \mathrm{L}$ of T4-DNA ligase, the whole volume $(20 \mu \mathrm{L})$ was mixed, centrifuged briefly and incubated at room temperature for $2 \mathrm{~h}$. The restricted-ligated reaction was diluted 1:5 using TE buffer (10 mM Tris-base, 1 mM EDTA, PH 8.0).

\subsection{Pre-amplification Reaction}

The pre-amplification reaction was prepared with a final volume of $20 \mu \mathrm{L}$ containing $2 \mu \mathrm{L}$ of the above diluted ligation- reaction, $16 \mu \mathrm{L}$ of PCR master mix containing the pre-amplification primers and $0.15 \mu \mathrm{L}$ Taq DNA polymerase. Or $(16 \mu \mathrm{L}$ of two primers mix and $2 \mu \mathrm{L}$ of AFLP-PCR buffer and $0.15 \mu \mathrm{L}$ Taq DNA polymerase). The PCR amplification was performed for 20 cycles as followed: denaturation at $95{ }^{\circ} \mathrm{C}$ for 30 $\mathrm{s}$, annealing at $56{ }^{\circ} \mathrm{C}$ for 1 minute, and extension $72{ }^{\circ} \mathrm{C}$ for $1 \mathrm{~min}$. The pre-amplified DNA was diluted 1:5 using TE buffer.

\subsection{Selective AFLP Amplification}

The amplification reaction volume contained 8.32 $\mu \mathrm{L}$ of water, $2.5 \mu \mathrm{L}$ of the diluted pre-amplified reaction, $1 \mathrm{mM}$ AFLP-PCR buffer, $0.09 \mu \mathrm{L}$ and 2.25 $\mu \mathrm{L}$ of the two combinations P16+ M88 and P16+ M 17 respectively (Table 1 ) and $0.079 \mu \mathrm{L}$ Taq DNA polymerase. The PCR conditions included a touchdown program with 13 cycles of the denaturation at $94{ }^{\circ} \mathrm{C}$ for $30 \mathrm{~s}$, annealing at $65{ }^{\circ} \mathrm{C}$ for $30 \mathrm{~s}$, decreased by $0.7^{\circ} \mathrm{C}$ per cycle, and extension at $72{ }^{\circ} \mathrm{C}$ for $60 \mathrm{~s}$ after each cycle. This was followed by another 23 cycles of $94{ }^{\circ} \mathrm{C}$ for $30 \mathrm{~s}, 56{ }^{\circ} \mathrm{C}$ for $30 \mathrm{~s}$, and $72{ }^{\circ} \mathrm{C}$ for $1 \mathrm{~min}$.

\subsection{Separation of Amplified DNA Molecules on Acrylamide Gel}

The selective amplification products $(10 \mu \mathrm{L})$ were denatured at $94{ }^{\circ} \mathrm{C}$ for $5 \mathrm{~min}$ and placed immediately on ice, then separated in $6 \%$ denaturing polyacrylamide gel electrophoresis at $70 \mathrm{~W}$ and $50{ }^{\circ} \mathrm{C}$ for $2 \mathrm{~h}$, and the products were visualized by silver staining.

\subsection{Gel Staining}

The PCR products were visualized using silver staining as followed: the gel was prefixed by putting in a glacial acetic acid solution, and stained with silver nitrate. The DNA bands was visualized by a developing solution of sodium carbonate and thiosulfate, and then fixed using aglacial acetic acid solution again. The gel photo was transferred to the computer for analyzing the data.

\subsection{Data Analysis}

After the DNA was amplified according to the method described by Zabeau and Vos [26], and modified

Table 1 Sequence of the Primers used for the amplification of the initial test (P16 + M88), (P16 + M17) AFLP.

\begin{tabular}{|c|c|}
\hline Primer & Nucleotide sequence \\
\hline Pst0 & 5`GACTGCGTCCATGCAG \\
\hline Pst1+ CC & 5`GACTGCGTCCATGCAG CC \\
\hline Mse1 +CG & $5^{`}$ GATGAGTCCTGAGTAA CG \\
\hline Mse0 & 5` GATGAGTCCTGAGTAA \\
\hline Pst1+ CC & 5`GACTGCGTCCATGCAG CC \\
\hline Mse 1+ GC & 5` GATGAGTCCTGAGTAA CG \\
\hline
\end{tabular}



Stripe (yellow) Rust Puccinia striiformis f.sp tritici during 2010-2014 in Some Regions of Syria

by Van et al. and Poowell et al. [27, 28]. PCR products were visualized on acrylamide gel and the data were constructed in an Excel file as a binary matrix for each AFLP fragment ranged between 1,500-100 bp. The data were then analyzed in Power Marker 3.25 [29]. The genetic variance was evaluated based on both of Shannon's diversity index and genetic diversity index, the Principal Co-ordinates Analysis (PCoA) was performed according to the genetic distance, the Correlation Coefficients Matrix and the distance between races [30]. The Analysis of Molecular Variance (MOVA) was done between the fungus races; also the phylogenetic tree of all races was constructed.

\section{Results and Discussion}

\subsection{Nomenclature Races of the Stripe Rust}

The species $P$. striiformis f. sp. tritici, causing stripe rust on wheat, are further separated into races according to virulence against cultivars or genotypes of wheat. Races are differentiated by infection types on two groups of selected wheat genotypes: the "world differentials" and the "European differentials" [25]. The survey has been conducted in main wheat growing areas of Syria, during two seasons; 2010 and 2011-2014. According to Johnson et al. [25], the nomenclature of 55 single spore isolates, represented 40 different races; 25 ones were recorded only for one season (Fig. 1). Thus, 15 races of yellow rust had been addressed in Syria for season 2010-2014, 159E256, 6E16, 166E254, 166E256, $255 \mathrm{E} 112,0 \mathrm{E} 0,64 \mathrm{E} 6,230$ E150, 0 E18, 198 E130, 166 E150, 102 E160, 128 E0, $126 \mathrm{E} 150,214 \mathrm{E} 150$ (Tables 1 and 2), 7 of them (159E256, 166 E150, 166E254, 166E256, 214E150, $230 \mathrm{E} 150$ and $255 \mathrm{E} 112)$ contained the virulence gene Yr27 (Tables 2 and 3). The 6E16 race was the most frequent during the two seasons, while the race $255 \mathrm{E} 112$ was the most virulent, followed by the race 230E222, and the $0 \mathrm{E} 0$ race was the weakest one. Moreover, this study revealed presence of fourteen newly observed races in Syria.

The result showed that AFLP amplification test with both primers' combinations $P 16+M 17$ and $P 16+M 88$ had the best efficiency and produced the most

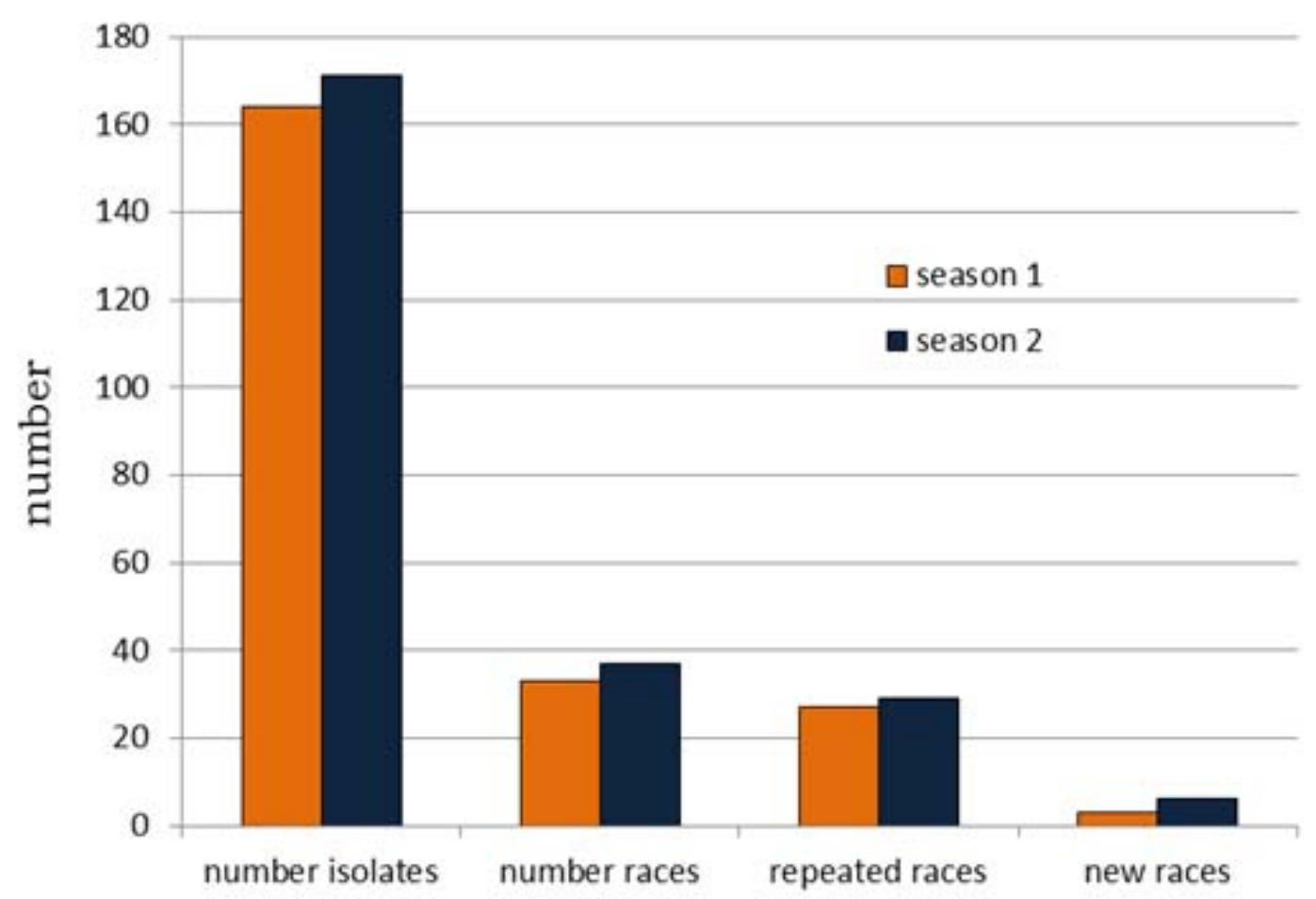

Fig. 1 Number of isolates, identified races, repeated races and new races (2010-2014). 


\section{Study Genetic Variation Using DNA Molecular Markers and Identification Physiological Races of Wheat 165 Stripe (yellow) Rust Puccinia striiformis f.sp tritici during 2010-2014 in Some Regions of Syria}

Table 2 Physiological races of the fungus yellow rust on wheat registered in Syria and its pathogenicity genes during the 2010.

\begin{tabular}{|c|c|c|}
\hline Pathogenicity genes & Races & N. \\
\hline Yr6, Yr7, Yr9+, Yr7+, Yr6+, Yr3N, YrSP, Yr2+, Yr2A, YrA+, Yr9 Gereck 79 & 230 E 222 & 1 \\
\hline Yr6, Yr7, Yr1, Yr7+, YrSD, YrSU, Yr9+, Yr6+, Yr8, Yr2A, Yr9 Gereck 79, Yr27 & 230 E 150 & 2 \\
\hline $\operatorname{Yr} 7, \operatorname{Yr} 6, \operatorname{Yr} \mathrm{SU}, \operatorname{Yr}$ 2,+, $\operatorname{Yr}$ 7+, $\operatorname{Yr}$ 6+, $\operatorname{Yr}$ 8, $\operatorname{Yr} 2 \mathrm{~A}, \operatorname{Yr}$ A+, $\operatorname{Yr}$ 9, Gereck 79 & 198 E 130 & 3 \\
\hline Yr6, Yr7, YrSU, Yr9+, Yr6+, Yr9, Gereck 79 & 198 E4 & 4 \\
\hline $\operatorname{Yr} 6, \operatorname{Yr}$ 9+, $\operatorname{Yr} 7+, \operatorname{Yr} 8, \operatorname{Yr}$ SP, $\operatorname{Yr} 2 \mathrm{~A} \operatorname{Yr}$ A, $\operatorname{Yr}$ 9, Gereck & 196 E 98 & 5 \\
\hline Yr6, Yr7, Yr9+, Yr7+, Yr6+, Yr8, Yr2+, Yr2A, YrA+, Yr9 Gereck 79 & 166 E150 & 6 \\
\hline $\operatorname{Yr} 7, \operatorname{Yr} 6, \operatorname{Yr} \mathrm{SU}, \operatorname{Yr} 6,+, \operatorname{Yr} 7+, \operatorname{Yr} 2+, \operatorname{Yr} 2 \mathrm{~A}, \operatorname{Yr} \mathrm{A}+, \operatorname{Yr} 9$, Gereck 79 & 164 E 22 & 7 \\
\hline $\operatorname{Yr} 6, \operatorname{Yr} 7, \operatorname{Yr} 9+, \operatorname{Yr} 7+, \operatorname{Yr} 6+, \operatorname{Yr} 3 \mathrm{~N}, \operatorname{Yr} 2+, \operatorname{Yr} 2 \mathrm{~A}, \operatorname{Yr} \mathrm{A}+, \operatorname{Yr} 9$ Gereck 79 & 142 E 130 & 8 \\
\hline Yr9+, Yr7, Yr6, Yr9+, Yr 8, Yr2A, YrA+, Yr9, Gereck 79 & 134 E 16 & 9 \\
\hline Yr2+, Yr2A, YrA+, Yr9, Gereck 79, Yr7, Yr7+, Yr 3N, YrSD & $126 \mathrm{E} 150$ & 10 \\
\hline Yr9+, Yr2A, Yr9, Gereck 79 & $128 \mathrm{E} 0$ & 11 \\
\hline Yr6+, Yr SU, $\operatorname{Yr}$ SD, $\operatorname{Yr} 10, \operatorname{Yr} 8, \operatorname{Yr} 2 \mathrm{~A}, \operatorname{Yr} \mathrm{A}$ & 114 E 16 & 12 \\
\hline Yr 7, Yr 6, Yr SU, Yr CV, Yr 2+, Yr 2A, Yr A+, Yr 9, Gereck 79 & 102 E 160 & 13 \\
\hline $\operatorname{Yr} \mathrm{SU}, \operatorname{Yr} \mathrm{SD}, \operatorname{Yr} 7+, \operatorname{Yr} 6+, \operatorname{Yr} 8, \operatorname{Yr} \mathrm{CV}, \operatorname{Yr} 2 \mathrm{~A}, \operatorname{Yr} \mathrm{A}+, \operatorname{Yr} 9$, Gereck 79 & 82 E 16 & 14 \\
\hline $\operatorname{Yr} 7, \operatorname{Yr} 3 \mathrm{~N}, \operatorname{Yr} \mathrm{SU}, \operatorname{Yr} 6+, \operatorname{Yr} 7+, \operatorname{Yr} 8, \operatorname{Yr} 2 \mathrm{~A}, \operatorname{Yr} \mathrm{A}+, \operatorname{Yr}$ 9, Gereck 79 & 78 E 30 & 15 \\
\hline Yr6, YrSU, Yr2+, Yr7+ Yr9, Gereck 79 & $68 \mathrm{E} 130$ & 16 \\
\hline $\operatorname{Yr} 6, \operatorname{Yr} 7, \operatorname{Yr} \mathrm{SD}, \operatorname{Yr} 6+, \operatorname{Yr} 7+, \operatorname{Yr} 8, \operatorname{Yr} 2+, \operatorname{Yr} 2 \mathrm{~A}, \operatorname{Yr} \mathrm{A}+$, Gereck 79 & 38 E 150 & 17 \\
\hline $\operatorname{Yr} 7+, \operatorname{Yr} 9, \operatorname{Yr} 2 \mathrm{~A}, \operatorname{Yr} 4$ & 36 E 6 & 18 \\
\hline Yr SD, $\operatorname{Yr}$ 9, Gereck 79 & 32 E 0 & 19 \\
\hline Yr 6, Yr r7, Yr SD, Yr 9, Gereck 79 & 20 E 0 & 20 \\
\hline $\operatorname{Yr} 6, \operatorname{Yr} 2+, \operatorname{Yr} 6+, \operatorname{Yr} 8, \operatorname{Yr} 9, \operatorname{Yr} 7+, \operatorname{Yr} 10$ & 16 E150 & 21 \\
\hline $\operatorname{Yr} 6, \operatorname{Yr} 6+, \operatorname{Yr} 8$, Gereck 79 & 6 E 30 & 22 \\
\hline $\operatorname{Yr} 6, \operatorname{Yr}$ r7, $\operatorname{Yr} 6+, \operatorname{Yr} 8, \operatorname{Yr} 2 \mathrm{~A}, \operatorname{Yr}$ A+, $\operatorname{Yr}$ 9, Gereck 79 & $6 \mathrm{E} 20$ & 23 \\
\hline $\operatorname{Yr} 6+, \operatorname{Yr} 7, \operatorname{Yr} 6, \operatorname{Yr} 9$, Gereck 79 & 6 E 16 & 24 \\
\hline Yr6, Yr7, Yr2A, YrA+, Yr9, Gereck 79 & $6 \mathrm{E} 0$ & 25 \\
\hline $\operatorname{Yr} 9, \operatorname{Yr} 6+, \operatorname{Yr} 7+, \operatorname{Yr} \mathrm{CV}, \operatorname{Yr} 6$ & $4 \mathrm{E} 40$ & 26 \\
\hline $\operatorname{Yr} \mathrm{CV}, \operatorname{Yr} 6, \operatorname{Yr} 2 \mathrm{~A}, \operatorname{Yr} 9$ & 4 E 32 & 27 \\
\hline $\operatorname{Yr} 6, \operatorname{Yr} 7+, \operatorname{Yr} 9$, Gereck 79 & $4 \mathrm{E} 2$ & 28 \\
\hline $\operatorname{Yr} 6, \operatorname{Yr} 2 \mathrm{~A}, \mathrm{Yr} 9$ & $4 \mathrm{E} 0$ & 29 \\
\hline $\operatorname{Yr} 7$ & $2 \mathrm{E} 0$ & 30 \\
\hline Yr 6, Yr 10, Yr 3V, Yr 9, Gereck 79 & 0 E 28 & 31 \\
\hline $\operatorname{Yr} 3 \mathrm{~N}, \operatorname{Yr} 6+, \operatorname{Yr} 7+$ & 0 E 18 & 32 \\
\hline++++ & 0 E 0 & 33 \\
\hline
\end{tabular}

polymorphic markers; 75 and 72 respectively, so they were used for the selective AFLP amplification with addition of two nucleotides (Pst1+ CC, Mse1 +CC) and (Pst1+ CC, Mse1+GC), that produced 278 and 302 bands respectively (Figs. 2 and 3), using Adobe Photoshop CS software for reading the gel.

There was no significant difference between the geographic regions, as the PIC was $31.51 \%$. Also, the results of AMOVA pointed out that the variation of the races among the regions was $10 \%$ only, and $90 \%$ within the region, while the variance components were
$2.5 \%$ and $97.51 \%$, respectively (Table 4 ).

In addition, the clustering analysis of the races showed similar results related to genetic variance, using either the PCoA or UPGMA (Fig. 4). The races, representing one area, were separated into different groups, while those related to geographically different areas clustered in same groups, and these results agree with previous studies [31, 32], since the yellow rust spores can travel with air for far distance to anywhere [33], so it is more likely to be one region invaded by many different races simultaneously. 

Stripe (yellow) Rust Puccinia striiformis f.sp tritici during 2010-2014 in Some Regions of Syria

Table 3 Physiological races of the fungus yellow rust on wheat registered in Syria and its pathogenicity genes during the 2011-2014.

\begin{tabular}{|c|c|c|c|}
\hline N. & Differential cultivars & The resistant gene & The race \\
\hline 1 & Chinese 166 & -------------------------------- & $0 \mathrm{E} 0$ \\
\hline 2 & Lee & Yr7, Yr6, Yr 8, Gereck 79 & $6 \mathrm{E} 16$ \\
\hline 3 & Heines Kolben & Yr6, Yr7, Yr2A, YrA+, Yr9, Gereck 79 & $6 \mathrm{E} 0$ \\
\hline 4 & Vilmorin 23 & Yr6, Yr7, Yr1, Yr7+, YrSD, YrSU, Yr9+, Yr6+, Yr8, Yr2A, Yr9 Gereck 79, Yr27 & $230 \mathrm{E} 150$ \\
\hline 5 & Moro & $Y r 7+Y r 9, Y r 2 A, Y r 4$ & $6 \mathrm{E} 36$ \\
\hline 6 & Strubes Dickopf & Yr6+, Yr7+, Yr 9, Gereck 79 & 64 E 6 \\
\hline 7 & Suwon 92 x Omar & YrSU, YrSD, Yr7+, Yr6+, Yr8, YrCV, Yr2A, YrA+, Yr9, Gereck 79 & 82 E16 \\
\hline 8 & Clement & $\operatorname{Yr6}, \operatorname{Yr} 2 \mathrm{~A}, \operatorname{Yr} 9$ & $4 \mathrm{E} 0$ \\
\hline 9 & Triticum spelta & Yr7 & $2 \mathrm{E} 0$ \\
\hline 10 & Hybrid 46 & Yr9+, Yr2A, Yr9, Gereck 79 & $128 \mathrm{E} 0$ \\
\hline 11 & Reichersberg & Yr7, Yr6, YrSU, YrCV, Yr2+, Yr2A, YrA+, Yr9, Gereck 79 & $102 \mathrm{E} 160$ \\
\hline 12 & Heines peko & Yr6, Yr7, Yr9+, Yr7+, Yr6+, Yr8, Yr2+, Yr2A, YrA+, Yr9 Gereck 79, Yr27 & 166 E150 \\
\hline 13 & Nord Desprez & Yr7, Yr6, YrSU, Yr2+, Yr7+, Yr2A, YrA+, Yr9, Gereck 79 & $198 \mathrm{E} 130$ \\
\hline 14 & Compare & Yr9+, Yr2A, Yr8, Yr7 & $0 \mathrm{E} 18$ \\
\hline 15 & Carstens V & Yr 1, Yr3V, YrSU, Yr6, Yr7, Yr10, Yr9+, Yr8, Yr SD, Yr SP, Yr CV, Yr2A, Yr 9, Yr27 & $255 \mathrm{E} 112$ \\
\hline 16 & Spaldings prolific & $\operatorname{Yr} 1, \operatorname{Yr} 3 \mathrm{~V}, \operatorname{YrSU}, \operatorname{Yr} 6, \operatorname{Yr} 7, \operatorname{Yr} 10, Y r 9+, Y r 8, \operatorname{Yr} \mathrm{SD}, \operatorname{Yr} \mathrm{SP}, \operatorname{Yr}, \operatorname{Yr} 27, \mathrm{CV}, \operatorname{Yr} 2 \mathrm{~A}, \operatorname{Yr} 9$ & 166 E256 \\
\hline 17 & Heines VII & Yr7, Yr6, YrSD, YrSU, Yr2+, Yr3V, Yr9+, Yr6+, Yr8, Yr7+, Yr2A, YrA, Yr27, Yr 9 & 166 E254 \\
\hline 18 & Anza & Yr27, CV, Yr2A, Yr 9, Yr6, Yr7, Yr9+, Yr7+, Yr6+, Yr8, Yr2A, YrA+, Yr9 Gereck 79 & 159 E256 \\
\hline 19 & Sonalika & YrCV, Yr7, Yr6, YrSU, Yr2+, Yr7+, Yr2A, YrA+, Yr9, Gereck 79 & 166 E120 \\
\hline 20 & Fed.4/Kavkaz & Yr2+, Yr2A, YrA+, Yr9, Gereck 79, Yr7, Yr7+, Yr 3N, YrSD & $126 \mathrm{E} 150$ \\
\hline 21 & Gereck 79 & Yr27, YrSU, YrSD, Yr7+, Yr6+, Yr8, YrCV, Yr2A, YrA+, Yr9, Gereck 79 & 214 E150 \\
\hline 22 & Cham1 & Yr9, YrA+, Yr2A, Yr8, Yr7+, Yr6+, Gereck 79 & 134 E16 \\
\hline
\end{tabular}

As that, all races were clustered in four major groups:

Group A: included races belonging to geographic areas near each other; Idlib, Hama and Aleppo, in addition to farther one; Tel Hadya. The genetic relation was only $35.3 \%$ according to the values of Bootstrap.

This group contained the races: 230E222, 230E150, 198E130, 196E98, 198E4, 164E22, 142E130, 128E0, 114E16, 102E160, 82E16, 38E150, 36E6, 32E0, 20E0, 14E150, 6E30, 6E20, 6E16, 6E0, 4E40, 4E2, 2E0, 0E28, 0E18, 0E0.

Group B: the genetic relationship was $15.3 \%$, that suggested races of geographically different areas; Dara, Deir AL-Zor and Raqqa. These races are 230E150, 198E130, 134E16, 126E150, 78E30, 38E150, 36E6, 6E16, 4E2 and 4E0.

Group C: contained races from Idlib and Aleppo and Hasaka with a genetic relation was $22.3 \%$, and included the races: 230E222, 6E150, 36E150, 36E6,
6E36, 6E30, 6E16, 4E32, 2E0 and 0E0.

Group D: contained races from Tartous, Homs, Hasaka and Damascus and Latakia The degree of relationship was 42\%, and represented the races: 255 E112, 230E150, 214E150, 198E130, 166E256, 166E254, 166E150, 159E256, 128E0, 126 E150, 102 E160, 64 E6, 6E16, 0E18, 230E222, 230E150, 38E150, 6E16, 6E0, 4E0 and 0E0.

The results showed the high similarity among the races representing farther different areas in geography and environment, such as the similar races of Aleppo and Hasakah, and the other races of Aleppo were similar to that of Tartous, Hamah and Tal-hadia (Fig. 5). These can be referred to the transmission of fungus spores by air and spread to far places [34], and the usual pathways of the local wind during the infection season in the spring might play a critical role in the genetic similarity of races among the provinces [35], as the wind generally blows from west to east. 
Study Genetic Variation Using DNA Molecular Markers and Identification Physiological Races of Wheat 167 Stripe (yellow) Rust Puccinia striiformis f.sp tritici during 2010-2014 in Some Regions of Syria

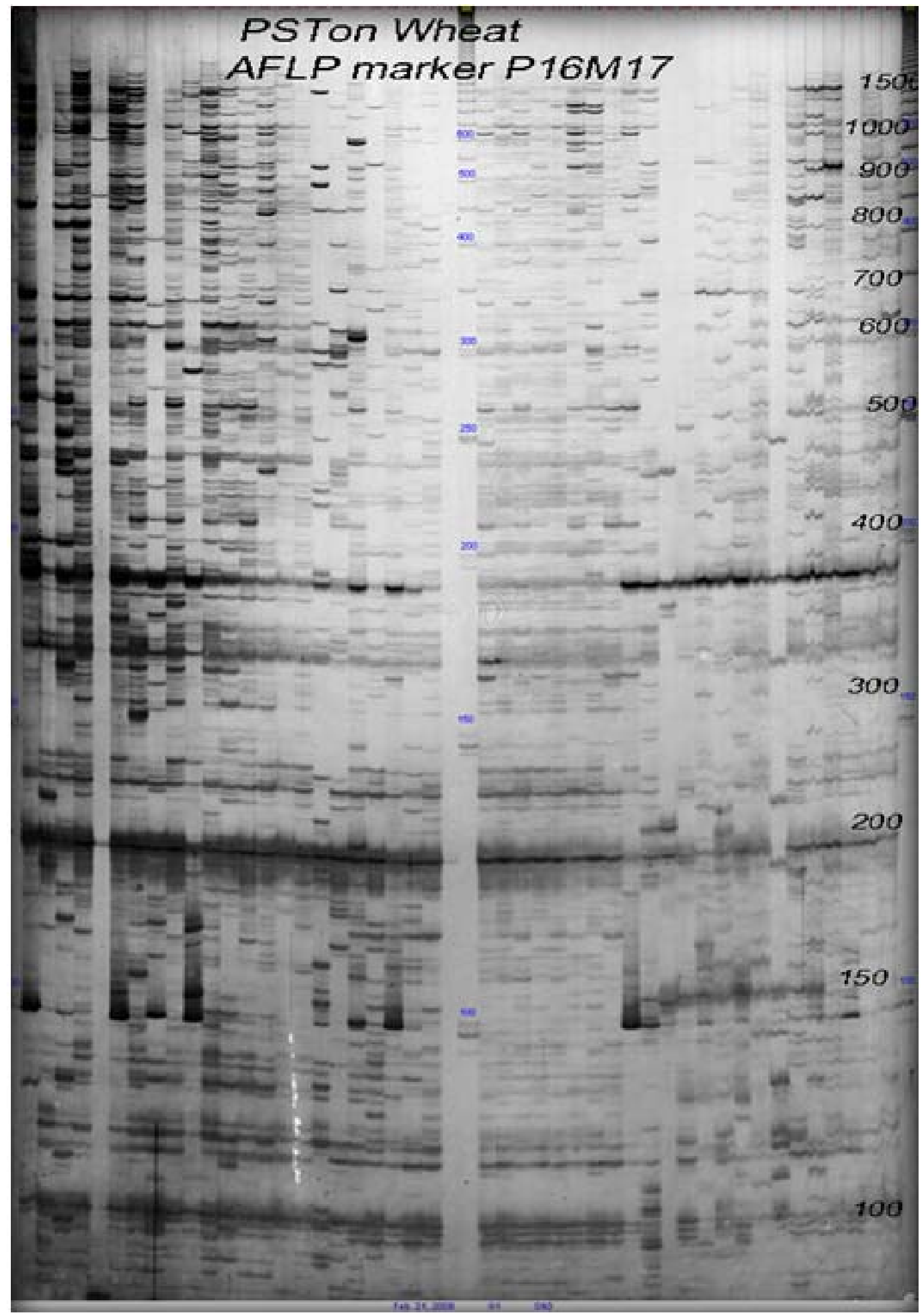

Fig. 2 AFLP product of yellow rust isolates using Primers P16+M $17($ Pst1 $+C C$, Mse $1+C C)$. 


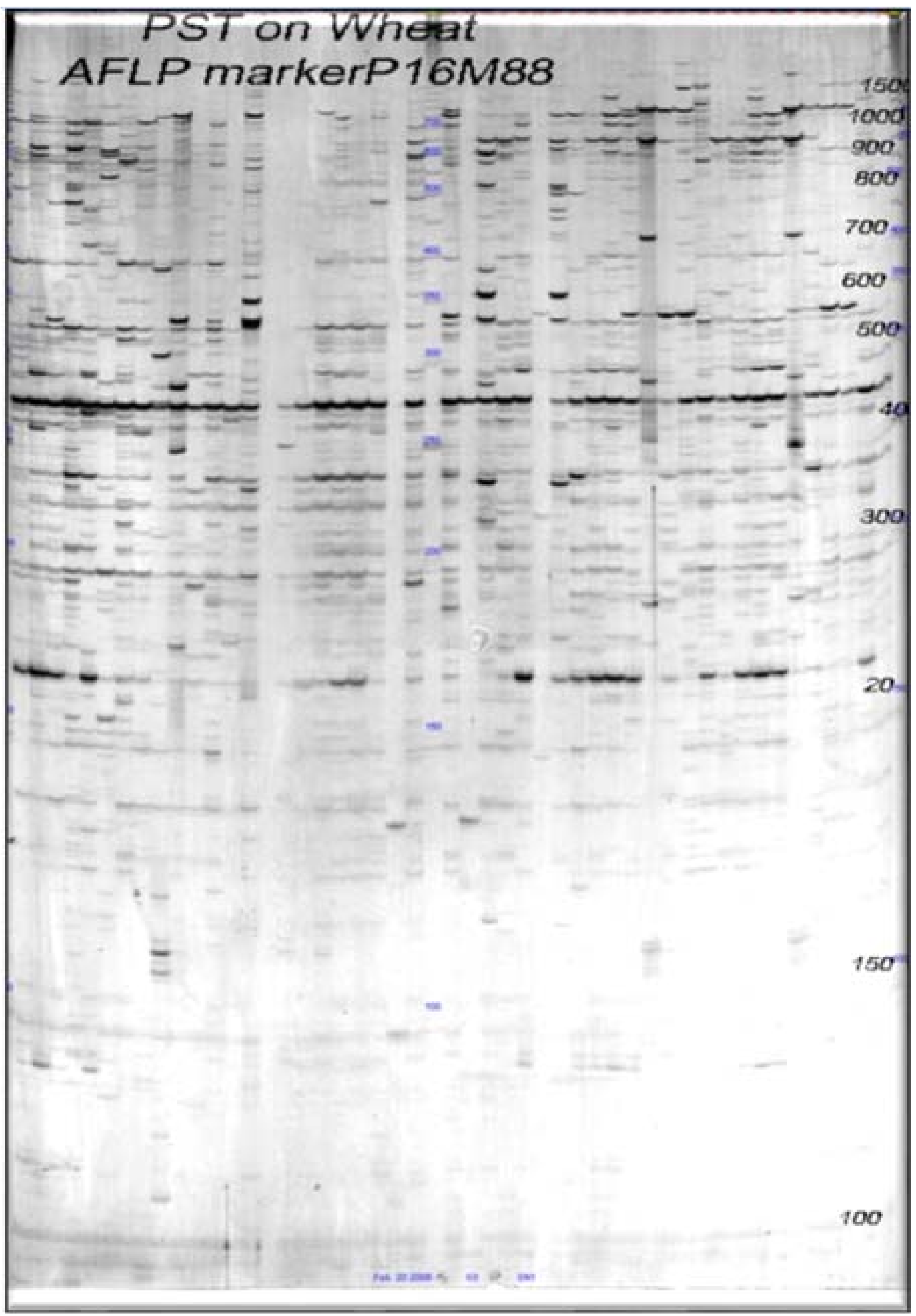

Fig. 3 AFLP product of yellow rust isolates using Primers P16 + M88 (Pst1+ CC, Mse1 +GC). 
Study Genetic Variation Using DNA Molecular Markers and Identification Physiological Races of Wheat Stripe (yellow) Rust Puccinia striiformis f.sp tritici during 2010-2014 in Some Regions of Syria

Table 4 Analysis of partial contrast to the races of the fungus yellow rust between the studied sites in the Syrian society.

\begin{tabular}{lllll}
\hline Source of variation & Degree of freedom & Sum of squares & Contrast components & Contrast Ratio \\
\hline Between of cities & 10 & 507.602 & 50.760 & $10 \%$ \\
Within the city & 85 & $2,302.377$ & 27.087 & $90 \%$ \\
Total & 95 & $2,809.979$ & 77.847 & \\
\hline
\end{tabular}

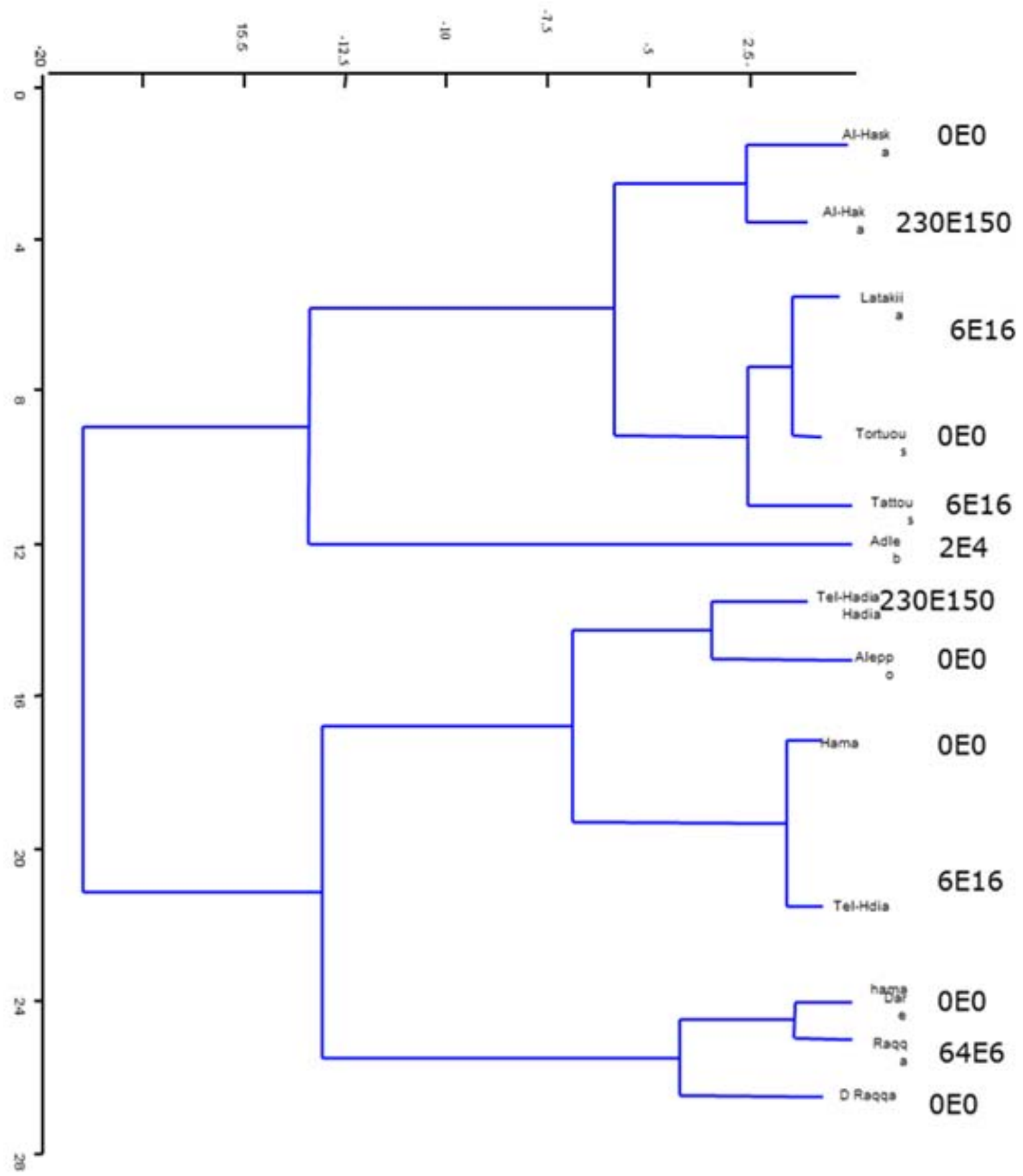

Fig. 4 Dendrogram of yellow rust races on wheat according to Ref. [29]. 


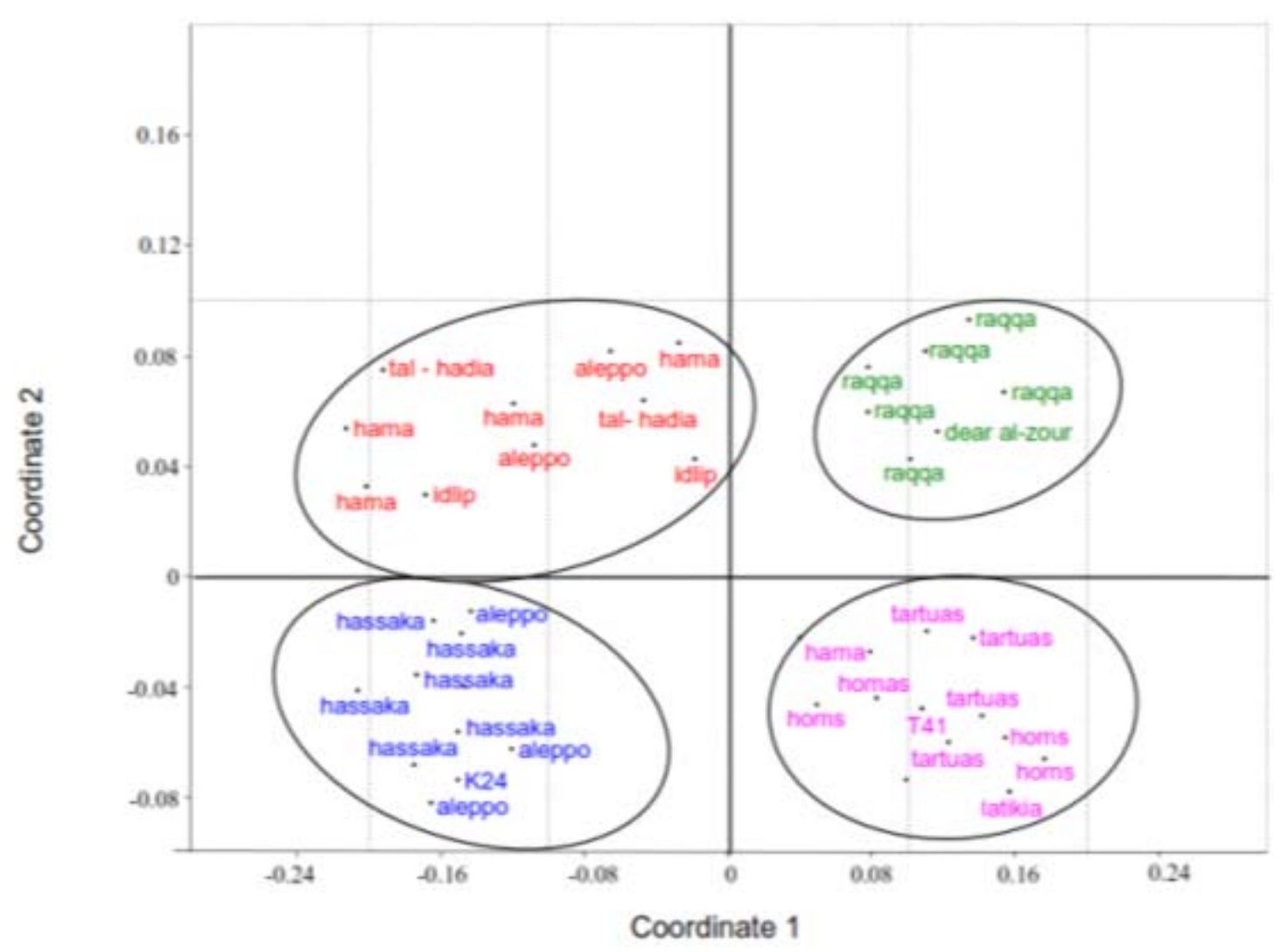

Fig. 5 The results of meta-analysis of genetic tree between fungus yellow rust on wheat races during 2010-2014 [40].

AFLP technique could determine the genetic diversity within the yellow rust community, since it could detect 147 polymorphic sites, i.e. 97.5\%. This might declare the epidemic kinetics of this fungus, but couldn't reveal its kinetics within the field [36].

Moreover, the races of Idlib and Aleppo shared many unique AFLP markers, compared with those between Tal-Hadia and Algab that had more polymorphic markers. The result could be explained by the effect of the north area on Tal-Hadia, while the site of Idlib and Aleppo probably involved other cumulative effects.

In specific words, in addition to Tal-Hadia is the most vulnerable area to the fungus infection, it is artificially infected with different races from other areas annually, as it is planted with various genotypes of wheat that have varying capability to infect with this pathogen [37] (have varying degrees of susceptibility against this pathogen), all of that factors increases the probability for emerging of new races from thus complex fungal community.

In the north region, UPGMA analysis determined 10 groups with $69.73 \%$ similarity, one of them had 11 different types including type 0 , i.e. $90 \%$ of races. That might suggest more study to have more specific results about the genetic structure of the pathological zone [38]. North Syria is affected with the fungal Turkish community by wind which carries the Uredospore's faraway up to $800 \mathrm{Km}$ [39], so it might suppose that the whole genetic variance in this area is derived from differentially genetic material belonging either to a major source; type 0 , to other ones come from immigrated spores, or the survival ones along the summer. 


\section{Study Genetic Variation Using DNA Molecular Markers and Identification Physiological Races of Wheat Stripe (yellow) Rust Puccinia striiformis f.sp tritici during 2010-2014 in Some Regions of Syria}

In this work, there were two virulent genotypes: 230 E 222 and 230 E 150, separating into different groups with $88.7 \%$ similarity, which proposed that AFLP markers were unrelated to the virulence [40]. Also, the dendrogram confirmed that, as the bootstrap value was $11.33 \%$ and the genetic distance between two genotypes was $4.1 \%$ only, while the number of alleles was $68.23 \%$.

\section{Conclusion}

P. striiformis f. sp. tritici communities could be similar over all the fields in north Syria, as that must be considered in developing a new strategy of wheat breeding to resist this pathogen.

\section{References}

[1] Moldenhauer, J., Moerschbacher, B. M., and Van Der Westhuizen, A. J. 2006. "Histological Investigation of Stripe Rust (Pucciniastriiformis f. sp. tritici) Development in Resistant and Susceptible Wheat Cultivars.” Plant Pathol. 55: 469-74.

[2] Roelfs, A. P., Singh, R. P., and Saari, E. E. 1992. Rust Diseases of Wheat: Concepts and Methods of Disease Management. Mexico. D. F: CIMMTY. 81.

[3] Lessa, E. P. 1990. "Multidimensional Analysis of Geographic Genetic Structure.” Systematic Zoology 39: 242-52.

[4] Stubbs, R. W. 1988. "Pathogenicity Analysis of Yellow (Stripe) Rust of Wheat and Its Significance in a Global Context.” Breeding Strategies for Resistance to the Rust of Wheat, 23-38

[5] Johnson, R. 1988. "Durable Resistance to Yellow Rust in Wheat and Its Implications in Plant Breading." In Breading Strategies for Resistance to Rusts of Wheat. Edited by Simmonds, N. W., and Rajaram, S. CIMMTY. 151: 63-75.

[6] Stubbs, R. W., Prescott, J. M., and Dubin, E. E. 1986, "Cereal Diseases Methodology Manual International Maize and Wheat Important Center (CIMMYT) in Cooperation with Research Institute for Plant Protection (IPO).” Wageningen the Nether land, 46.

[7] Murray, T. D., Parry, D. W., and Cattlin, N. D. 1998. A Colour Handbook of Diseases of Small Grain Cereal Crops. London: Manson Publications.

[8] Yahyaoui, A. H., Hakim, M. S., and Naimi M. El. 2002. "Evolution of Physiologic Races and Virulence of Pucciniastriiformis on Wheat in Syria and Lebanon.” Plant Disease 68: 499-506.
[9] Mamluk, O. F., and AL Naimi, M. 1992. "Occurrence and Virulence of Wheat Yellow Rust in Syria." In Proceeding European and Mediterranean Cereal Rusts and Mild News Conference, edited by Zeller, F. J., and Fischbeek, G. September 8-11, 1992, Wheitenstephea Germany, 115-7.

[10] Yahyaoui, A. 2010. "Virulence of Wheat Yellow Rust on Field Grown Yellow Rust Differentials.” Turkish and Regional Wheat Varieties in Ankara. Germplasm Program Cereal Report for 2.

[11] Yahyaoui, A. 2002. "Cereal Diseases in CWANA and Gene Development Strategies Nabeul.” Tunisie November 10: 305-13.

[12] Rust, K. A., Humphreys, E., Wellings, C. R., and Dickinson, M. J. 2001. "Support for A Stepwise Mutation Model for Pathogen Evolution in Australasian Puccinia striiformis f. sp. tritici by Use of Molecular Markers.” Plant Pathology 50: 174-80.

[13] Stubbs, R. W. 1985. "Stripe Rust.” The Cereal Rusts. Vol II. Edited by Roelfs, A. P., and Bushnell, W. R. London: Academic Press, 61-101.

[14] Justesen, A. F., Bayles, C. J., and Hovmller, M. S. 2002. "The Recent History of Puccinia striiformis f. sp. tritici in Denmark as Revealed by Disease Incidence and AFLP Markers.” Plant Pathology 51: 13-23.

[15] Hammer, M., Harper, D. A. T., and Ryan, P. D. 2001. PAST: Pathological Statistics Bread Ware Package for Education and Data Analysis. Pathological Electronica 4 (1): 9.

[16] Gassner, G., and Straib, W. 1932. "Die Bestimmung der Biologischen Rassen Des Weizengelbrostes (Puccinia glumarum f. sp. tritici (Schmidt.) Erikss. und Henn.).” Arb. Biol. Reichsanst. Land Forstw. 20: 141-63.

[17] Hovmøller, M. S., and Justesen, A. F. 2007. “Appearance of Atypical Pucciniastriiformis West f. sp. tritici Phenotypes in North-Western Europe.” Australian Journal of Agricultural Research 58: 518-24.

[18] Bux, H., Ashraf, M., Rasheed, A., Kazi, A. G., Poudyal, D. S., and Afzal, M. 2012. "Molecular Basis of Disease Resistance in Cereal Crops: An Overview.” Crop Production for Agricultural Improvements. Edited by Ashraf, M., O” ztu“ rk, M., Ahmad, M. S. A., and Aksoy, A. New York: Springer, 478-86.

[19] Keiper, F. J., Hayden, M. J., Park, R. F., and Wellings, C. R. 2003. "Molecular Genetic Variability of Australian Isolates of Five Cereal Rust Pathogens.” Mycological Research 107: 545-56.

[20] Repally, F. 1979. "Yellow Rust Epidemiology.” Annu. Rev. Phytopathol. 17: 59-73.

[21] Enjalbert, J., Duan, X., Leconte, M., Hovmoller, M. S., and de Vallavieille, P. 2005. "Genetic Evidence of Local Adaptation of Wheat Yellow Rust Pucciniastriiformis f. 
172 Study Genetic Variation Using DNA Molecular Markers and Identification Physiological Races of Wheat Stripe (yellow) Rust Puccinia striiformis f.sp tritici during 2010-2014 in Some Regions of Syria

sp .tritici) within France.” Molecular Ecology 14: 16-20.

[22] McIntosh, R. A., Devos, K. M., Dubcovsky, J., Rogers, W. J., Morris, C. F., Appels, R., and Anderson, O. D. 2005. "Catalogue of Gene Symbols for Wheat: 2005 Supplement."

http://www.shigen.lab.nig.ac.jp/wheat/komugi/genes/mac gene/.

[23] McNeal, E. H., Knozak, C. F., Smith, E. P., Tate, W. S, and Russel, T. S. 1971. "A Uniforms System for Recording and Processing Cereal Research Data.” Agr. Res. Ser. publ ARS. 34-121 U.S., Dept. of Agriculture, Washington.

[24] Mc Donald, B. A., and Martinez, J. P. 1991. "DNA Fingerprinting of the Plant Pathogenic Fungus (Mycosphaenella graminicola) Anamorphic Septoriatritici).” Exp. Mycol. 15: 146-58.

[25] Johnson, R., Stubbs, R. W., Fuchs, E., and Chm Berlin, N. H. 1972. "Nomen Cloture for Physiologic Races of Puccinia striiformis in Fecting Wheat Trans.” Br Mycol. SOC. 58: 475-80.

[26] Zabeau, M., and Vos, P. 1993. "Selective Restriction Fragment Amplification: A General Method for DNA Fingerprinting.” European patent Application number: 9240269.7. Publication number 0: 534-858 AL.

[27] Van’ T., Slot, K. A. E., and Knogge, W. 2002. “A Dual Role for Microbial Pathogen-Derived Effectors Proteins in Plant Disease and Resistance." Crit. Rev. Plant Sci. 21: 229-71.

[28] Powell, W., Thomas, W. T. B., Buird, E., Lawrence, P., Booth, A., Harrower, B., McNical, J. W., and Waugh, R. 1997. "Analysis of Cuantitative Traits in Barley by the Use of Amplified Fragment Length Polymorphisms." Heredity 79: 48-59.

[29] Liu, K., and Muse, S. V. 2005. "Power Marker: Integrated Analysis Environment for Genetic Marker Data.” Bioinformatics 21: 2128-9.

[30] Nei, M. 1973. "Analysis of Gene Diversity in Subdivided Populations.” Proc. Natl. Acad. Sci. 70: 3321-3.

[31] Hovmoller, M. S., and Justesen, A. F. 2001. "Molecular Marker in Wheat Yellow Rust: I. Genetic Diversity and
Discussion of Their Usefulness in Survey Studies." In Meeting the Challenge of Yellow Rust in Cereal Crops, 175-6.

[32] Newton, A. C., Caten, C. E., and Johnson, R. 1985. "Variation for Isozyme and Double-A Stranded RNA among Isolates of Pucciniastriiformis and Two Other Cereal Rusts.” Plant Pathology 34: 234-47.

[33] Hovmoller, M. S., and Justesen, A. F. 2002. "Molecular Marker in Wheat Yellow Rust: II. Long-Distance Spread of Clones in Northwest Europe.” In Meeting the Challenge of Yellow Rust in Cereal Crops, 179-80.

[34] Chen, X. M. 2005. "Genetic Analysis and Molecular Mapping of Wheat Genes Conferring Resistance to the Yellow Rust on Wheat and Barley Yellow Rust Pathogens.” Theor. Appl. Genet. 95: 111-8.

[35] Mamluk, O. F., AI-Ahmed, M., and Makki, M. A. 1990. "Current Status of Wheat Diseases in Syria." Phytopathol. Mediterr 29: 143-50.

[36] Chen, X. M. 2005. "Epidemiology and Control of Yellow Rust [Pucciniastriiformis f. sp. tritici] on Wheat.” Neth. J. P. Path. 78: 258-64.

[37] Bux, H., Rasheed, A., Siyal, M. A., Alvina, G., Kazi, Napar, A. A., and Mujeeb-Kazi, A. 2012. "An Overview of Stripe Rust of Wheat (Puccinia striiformis f. sp. tritici) in Pakistan." Archives of Phytopathology and Plant Protection. DOI:10.1080/03235408.2012.726399.

[38] Enjalbert, J., Duan, X., Giraud, T., Vautrin, D., de Vallavieille-Pope, C., and Solignac, M. 2002. "Isolation of Twelve Microsatellite Loci, Using an Enrichment Protocol, in the Phytopathogenic Fungus Pucciniastriiformis f. sp. tritici." Molecular Ecology Notes 2: 563-5.

[39] Mamluk. 1995. "Variation in Virulence in Isolates of Mycosphaerella Wheat-Graminicola from Six Wheat Growing Geographical Regions.” Phytopathological Mediterranean 34: 45-51.

[40] Stam, P., and Lindhout, P. 2001. "Use of Locus-Specific AFLP Markers to Construct a High Density Molecular Map in Barley.” Theor. Appl. Genet 96: 376-84. 